participated. We also included two members of the staff of the SIU Public Policy Institute-former U.S. Senator Paul Simon and Mike Lawrence, former press secretary to Governor Jim Edgar-in our program.

Classroom time was supplemented with a one-week-long trip to the Illinois state capital in Springfield and a variety of sites in Chicago and a second one-week trip to Washington, DC. The week in Washington included a visit to the headquarters of the American Political Science Association and all participants received a complimentary one-year APSA membership. We also included a number of single- or partial-day trips during the time the group was in Carbondale in order to provide additional opportunities for a direct exposure to American politics, government, history, and culture. These included a day viewing the government and public works projects of Carbondale, a half-day observing the federal district court for our region, a visit to President Clinton's "New Markets Tour" appearance in East St Louis, Illinois, a picnic with a local grassroots interest group, a tour of a maximum-security prison, and a visit to the Fourth of July celebrations and historical sites in a nearby small town.

The 1999 institute was directed by John L. Foster, department of political science, SIUC. Co-directors of the program included John S. Jackson, chancellor of SIUC; Barbara L. Brown, department of political science, SIUC; and James G. Leibert, department of political science, Dickinson State University (ND). The 1999 participants were

Daniel Koboa Molaodi, lecturer, department of political and administrative studies, University of Botswana; Gaborone, Botswana

Jiang Yuan, associate professor of English and assistant director of American Studies Center, Sichuan University; Chengdu, China

Eduardo Barajas Sandoval, dean of the Schools of Political Science, Government and International Relations, Rosario University; Bogata, Colombia

\section{Washington Insider}

\section{Electronic Analogue of Library of Congress Proposed}

The National Research Council has proposed the development of an official international archive for digital publications.

In a November 1999 report titled "The Digital Dilemma: Intellectual Property in the Information Age" (http://books.nap.edu/books/0309064996/html/index.html), the NRC called for the formation of a task force with a two-year deadline for designing a system for the archiving, storing, and distributing digital publications.

Creating such an archive raises many important issues: Will authors grant per mission for storing and distributing their works? What is the most reliable medium for long-term data storage? Who will pay for maintaining the archive? While acknowledging that these and other questions will not be answered easily, the Council urged action on their proposal because much of this information is currently being lost.

\section{Federal Funding for Social and Behavioral Research Up for FY2000}

All but a few of the federal agencies that fund research in the social and behav ioral sciences will have more money to distribute this year than last. Making good on bipartisan promises to increase federal support for basic and applied research in all fields, Congress substantially raised the budgets for principle funding agencies like NSF and NIH. The full details of the FY2000 appropriations for social and behavioral sciences can be found in the December 6, 1999 issue of the Consortium of Social Science Association's Washington Update and online at www.apsanet.org/PS/washington/index.cfm.

\section{Important Washington People}

Wanda E. Ward has been named acting Assistant Director for the Social, Behavioral and Economic Sciences Directorate of the National Sciences Foundation. She replaces outgoing Bennett Bertenthal. Robert D. Reischaver assumed the presidency of the Urban Institute in February. He left The Brookings Institution to replace William Gorham, who led the Institute since its founding in 1968 .

\section{Follow Ups}

- In light of reports that several agencies would not be able to comply with his 1995 order to declassify a majority of their old records by April 2000, and evidence that others were unwilling to comply, President Clinton extended the deadline by 18 months. Under Executive Order 13142, federal agencies now have until October 17, 2001 to declassify all but the most sensitive of their records more than 25 years old. The order also provides that records requiring special review must be declassified by April 17, 2003.

- Public Citizen-joined by the American Historical Association, the Organization of American Historians, and others-petitioned the U.S. Supreme Court for a writ of certiorari regarding an August 1999 DC Circuit Court of Appeals ruling upholding the National Archives and Administration's policy of routinely deleting electronic records if a paper copy has been created. On December 28, 1999, NARA rescinded a draft policy for frequently than their male colleagues, regardless of discipline or institution. According to data compiled by Ernst Benjamin, director of storing and cataloging electronic records it issued earlier last year. The policies will be reissued following the resolution of the latest challenge to them. frequently than their male colleagues, regardless of discipline or institution. According to data compiled by Ernst Benjamin, director of

-The Jacob K. Javits Fellowship Program, the U.S. Department of Education program through which most federal support to doctoral and MFA students in the arts, humanities, and social sciences is distributed, again survived the budgetcutter's axe. It received funding through FY2002. 
Mirza Asmer Beg, lecturer, department of political science, Aligarh Muslim University; Aligarh, Uttar Pradesh, India

K.C. Srekumar, head, department of politics, N.S.S. College for Women; Thiruvananthapuram, Kerala, India

Alfian Muthalib, lecturer on the U.S. political system, American studies graduate program, University of Indonesia, and head, international relations department, National University; Jakarta,

Indonesia

Alma Urazbekova, teacher, political science department, Kazakh State University of International Relations and World Languages; Almaty, Kazakhstan

Irena Rajcinovska, junior assistant, law department, University of Skopje; Skopje, Macedonia

Neilson Ilan Mersat, head, program for politics and international studies, Faculty of Social Sciences, University of Malaysia Sarawak; Sarawak, Malaysia

Dorj Shurkhuu, senior research fellow, Center of International Sciences, Academy of Sciences; Ulaanbaatar, Mongolia

Panna Kaji Amatya, professor and head, central department of political science, Tribhuvan University; Kirtipur, Kathmandu, Nepal

Andre Krouwel, associate professor of political science, Free University of Amsterdam; Amsterdam, Netherlands

Omar Alberto Garcia, adjunct professor, faculty of social and judicial sciences, National Autonomous University of Nicaragua, Leon; Leon, Nicaragua
Manuel Filon Morar, teaching assistant, department of political science, University of Bucharest; Bucharest, Romania

Roy Jankielsohn, lecturer, department of political science, University of the Free State; Bloemfontein, South Africa

Salvador Marti, assistant professor of politics, Autonomous Univer- sity of Barcelona; Barcelona, Spain

Monia Ben Jemia, assistant professor of legal, political and social science, University of Tunis II; Tunis, Tunisia

Ngo Huy Duc, lecturer, Institute of Political Science, Ho Chi Minh National Political Academy; Hanoi, Vietnam

\section{Contributions to APSA Awards and Programs}

November 1999-January 2000

Ingrid Anderson

Allan R. Brown

Direlle R. Calica

James E. Campbell

Michael P. Canning

David A. Caputo

Philip E. Converse

Mark Curtis

Beth C. Fuchs

Irwin N. Gertzog

Col. Robert L. Goerder, Ret.

Esther S. Goldstein

Carol Hardy-Fanta

John P. Harrod

Paul S. Herrnson

Donald V. Hester

John F. Hoadley

J. Woodford Howard, Jr.

Betty G. Hubbell

Loch K. Johnson

Katherine M. Kaufer

Thomas A. Kazee

Margaret Keck

Stanley Kelley Jr.

Francis J. Keenan

Robert E. Lane

Lawrence LeDuc

Logan A. Lee

Ralph Lerner

Ann Chih Lin

\author{
Alice M. Litwinowicz \\ Robert Lorish \\ Donald J. Matthewson \\ Dalmas H. Nelson \\ Charldean Newell \\ Julie L. Novkov \\ Grady H. Nunn \\ William L. Oakley \\ Glenn R. Parker \\ Roy Parker, Jr. \\ Robert A. Pastor \\ Kelly D. Patterson \\ John J. Pitney \\ Lucian W. Pye \\ Bradley M. Richardson \\ Leroy N. Rieselbach \\ Raymond K. Rossiter \\ Susanne Hoeber Rudolph \\ Mark Sawyer \\ Jean Reith Schroedel \\ H. P. Secher \\ W. Scott Shrewsbury \\ Roberta S. Sigel \\ Andrea Y. Simpson \\ Theda Skocpol \\ James L. Sundquist \\ David Swickard \\ Ross B. Talbot \\ Jennifer Widner \\ Melissa S. Williams \\ John E. Yang
}

\section{Thank you!}

